\title{
Az emancipáció kérdése a két világháború közti nöknek szánt lapokban
}

\begin{abstract}
Engel Enikő
The Issue of Emancipation in between the Two World Wars in Journals Dedicated to Women

Abstract

The study examines the emancipation in Hungarian-language press articles written for the female community of the 1930s, in three different Central and Eastern European countries. The journals were published in Hungary, Romania, and Czechoslovakia. The introduction is about the changes affecting women in the early 20th century. In the next part, I deal with the employment of women, social changes that affect them, and the advancement of emancipation. This is followed by a structural analysis of the sheets. The focus of the study is on the articles related to emancipation. It also provides insight into how perceptions of women's employment, women's equality, and changes in women's roles in different press products for women were perceived in the 1930s.
\end{abstract}

Keywords: emancipation; press; women

Kulcsszavak: emancipáció; sajtó; nők

Subject-Affiliation in New CEEOL: History - Recent History - Interwar Period

DOI: 10.36007/eruedu.2021.1.039-055

\section{Bevezetés}

Az első világháború alatt és után a társadalmi szerepek olyan átalakuláson mentek át, amelyek addig példátlan módon változatták meg a nők társadalomban betöltött szerepét. Ezek a változások a nők szerepét egyre inkább a férfiakéhoz hasonlatossá tették, miközben az addig megszokott mindennapi életüket felforgatták. A nők alárendeltségének fokozatos megszünése megmutatkozott nemcsak az önállóan kereső nők számának megnövekedésében és az eltartottak csökkenésében, hanem a gondolkodásmódjukban is. 


\section{A 20. század eleji változások}

A 20. század kezdetén számos olyan változás zajlott le a társadalomban, amely lényegesen érintette a nöi nem képviselőit. Ezek közül az egyik legfontosabb a munkaerőpiacon bekövetkezett átalakulás volt, amely nemcsak hogy új foglalkozások kapuit nyitotta meg a női nem képviselői elött, de a tömeges munkába állásukat is magával hozta.

Mindez azonban nem ment gyorsan és föleg nem ment viták nélkül (Horváth 2017, 273). Csaknem egy évszázados folyamatos politikai csata eredményeként deklarálták a nők munkavállalási jogát, de még akkor is csak meghatározott területeken dönthettek szabadon a nők a munkavállalásról. A folyamat kezdete nagyon különböző módon zajlott az egyes országokban. Elsöként Angliában vette kezdetét a 18. században az ipari forradalom következményeként, a többi országban azonban a polgári átalakulás csak késöbb érezteti hatását, így ott csak a 19. században találkozunk elöször ezzel a kérdéssel.

Az újabb lökést a női munkavállalás terén az első világháború hozta meg, ugyanis ekkor minden országban jelentősen megemelkedett a nők foglalkoztatásának aránya. Ez azért következett be, mert ebben az időszakban a munkaképes férfi lakosság nagy része a frontokon harcolt (Mongu 2007, 279). A hátországokban a munkaerőhiány problémájának megoldására a nők foglalkoztatását látták a legjobb megoldásnak, egyre nagyobb mértékben és egyre szélesebb munkakörökben. Számos hölgy nehéz fizikai munkát kezdett végezni a fegyver és löszergyárakban a háború alatt. Sokan a frontvonal közelében ápolónőként tevékenykedtek. Ezen kívül egyre több nő jelent meg a szolgáltatóiparban; a kávéházakban, szállodákban, üzletekben és bankokban, akik általában megbecsült munkaerőnek számítottak megbízhatóságuk és igyekezetük miatt (Pukászky - Németh 2013, 176). A nők és anyák munkába állását számos új szolgáltatás is segítette. Ezek voltak az óvodák, napközik, menzák (Pető 2008, 81). Az első világháború után különféle szervezetek, főként a nőegyletek, a gyermekvédelmi egyesületek egyes állami hivatalokkal együtt próbáltak segíteni a falusi családok gondjain. Például a mezőgazdasági munkák idején sok faluban nyitottak nyári óvodát.

Az, hogy a nök új foglalkozásokban jelenhettek meg, összefüggött a tanulási lehetőségek kibővülésével. Az oktatás tömegessé válása előttük is kitárta az iskolák kapuit, beleértve az egyetemi képzést is. A nők aránya a felsőfokú intézményekben tekintélyes módon megnövekedett (Pukánszky - Németh 2013, 176). Azért is jelent meg ennyi nő a felsőoktatásban, mert sokaknak ez volt az egyetlen kiút az addigi tradicionális női szerepekböl, azonban az elhelyezkedési lehetöségeik így is korlátozottak maradtak a század elején (Bajcsi 2014, 137). A nők társadalmi, illetve családon belüli helyzetére nézve sokkal messzebbre ható, visszafordithatatlan következményekkel járt, hogy kiszélesedtek számukra a tanulási lehetöségek (Dudeková 2015, 318).

A 20. század kezdetén a legnépszerübb pálya a nők körében a tanári hivatás volt (Gyáni - Kövér 2006, 169). Ez a konzervatívabb társadalom számára is könnyen elfogadható volt, hiszen kapcsolatban állt a gyermekneveléssel, amiröl akkoriban azt tartották, hogy a tradicionális nőkép fontos építőeleme, tehát, ha a családoknak 
mindenképpen választaniuk kellett lányuknak valamilyen hivatást, akkor legtöbben a tanári mellett tették le voksukat (Gyáni - Kövér 2006, 169).

A politikában is számos nagy változás zajlott le, köztük a nőket leginkább a választójog széleskörű kiterjesztése érintette. Az első világháborúig a férfiak többsége már választópolgár volt. Az első világháború után azokban az országokban, ahol ez még nem történt meg, minden férfi, vagy legalábbis a többségük, megkapta a választójogot. A nőkkel kapcsolatban ez már nem mondható el, bár néhány országban már az első világháború előtt és alatt választójoghoz jutottak. Az első ilyen Finnország volt, itt már 1906-ban választójogot kaptak, ezt követte Norvégia, ahol 1913-ban kaptak a nők szavazati jogok, ezután pedig Dánia és Izland folytatta a sort 1915-ben.

A nők kilépése a háztartásokból és bekerülésük a munkaerőpiacra számottevő változáshoz vezetett az anyagi függetlenedésük terén. A nők azáltal, hogy dolgoztak, saját keresetre tettek szert, ami ahhoz vezetett, hogy megszünt az anyagi függésük és a kiszolgáltatottságuk a férjükkel szemben. A kenyérkereset egyfajta szabadságot és sokkal nagyobb mozgásteret jelentett a férjezett és hajadon hölgyeknek egyaránt. Már nem csupán feleségnek és anyának tekintették őket, de más szerepekben is kezdtek feltűnni és helytállni (Tomka 2006, 329).

A nök bekerülése a munkaerőpiacra, valamint a felsőfokú oktatásba jelentősen megváltoztatta a családstruktúrákat és nagyban befolyásolta a női emancipáció elörehaladását. A 20. század első évtizedeiben valamelyest nőtt az első házasságot kötők életkora a Szentpétervár-Trieszt-vonaltól keletre is. Ettől a vonaltól nyugatra ugyanis az ún. „európai házasodási minta” volt jellemző. Ezt a mintát már korábban is jellemezte a későbbi házasodás és gyermekvállalás, valamint a házasságra sosem lépők magas száma (Tomka 2006, 60). Ennek az egyik magyarázata a munkát vállaló nök számának növekedése lehet. Magyarországon 1930-ban mind a férfiak, mind pedig a nők esetében az első házasságkötés átlagos életkora csupán egy ével volt alacsonyabb a nyugat-európai átlagnál, Csehszlovákiában és Lengyelországban a nők esetében meg is egyezett azzal.

Az 1920-as évekre a nők szexualitáshoz való viszonyulása is szabadabb lett, dohányozni kezdtek, autót vezettek és olykor még ittak is. Az új nő tanult, dolgozott, voltak ambíciói, amelyek a klasszikus anya- és feleségszerepnél tovább nyúltak a dolgozó és a társadalom számára hasznos nő irányába. A modern nőhöz immáron hozzá tartozott a modern életstílus és a függetlenség a férfiaktól (Mongu 2007, 280).

A társadalmi megítélésük is módosulni látszott. 1918-ra az európai nőideál radikálisan megváltozott (Mongu 2007, 279). A hölgyek egyre több nyilvános helyen fordultak meg. Az egyik ilyen közkedvelt helyszín a mozi volt. A mozi közvetítője volt az új divatnak és életmódnak, amely szintén hatással volt magukra a nőkre, de a megítélésükre is (Tomka 2006, 219). Az amerikai nők ekkoriban a prototípusai voltak a modern, független, emancipált nöknek. (Tomka 2006, 281). Azt, hogy hogyan öltözködjenek, viselkedjenek, járjanak, gesztikuláljanak már a filmek és a hollywoodi sztárok is jelentősen alakitották. Ezek csakugyan részei voltak annak, hogy egész Európában a két világháború között a modern nő tulajdonságai egységesek voltak (Mongu 2007, 280). Azonban nemcsak Hollywood, de a dolgozó nők 
maguk is hozzájárultak a divat alakulásához, hiszen a kényelmetlen öltözékekben nem lehetett dolgozni, ezért a kényelmetlen ruhadarabokat felváltották a komfortos öltözékek.

A fentebb kifejtett változások nyomon követhetök a korabeli sajtótermékekben is. Az alábbiakban három, nőknek szánt sajtótermék segítségével nyerünk betekintést abba, hogy a korabeli lapok hogyan látták a női emancipáció kérdését és hogyan viszonyultak a női szerepek átalakulásához.

\section{A lapok jellemzöi}

A női közönség számára íródott lapok karrierje a 19. század közepén, de inkább a második felében indul útjára. Kelet-Európába a német nyelvterületröl érkeztek az első lapok, és a magyar változataik is német minta alapján honosodtak meg. Ezeknek a legelső típusú női lapoknak a divat, a szabás-varrás és a kézimunka volt a fö tárgya, amit kezdetben csak kiegészitettek a szépirodalmi és ismeretterjesztő cikkek. A század végére már olyan magyar nőknek szóló lapok is napvilágot láttak, amelyek nevelési, gazdasági és női érdekvédelmi szolgálatot kívántak ellátni (Fenyő - Ugrin - Kosáry - T. Erdélyi, 1985, 245).

A trianoni döntés után a kárpát-medencei magyarság egyharmada a szomszéd országok kisebbségeként élt tovább. Ezekben a Magyarországgal határos országokban a két háború között ugyanúgy müködött magyar nyelvü lapkiadás, amely követte a Trianon előtti hagyományokat, azonban a sajtótermékekre elég erősen hatott az újonnan alakult államok társadalmi-politikai kontextusa, ami egyfajta különfejlödést eredményezett. A tanulmány a női emancipáció témakörét vizsgálja három különböző közép-kelet európai országban megjelenő, magyar nyelvü, a harmincas évek női közönsége számára írt sajtótermékben. Ezek a sajtótermékek Csehszlovákiában, Romániában és Magyarországon jelentek meg. Míg a csehszlovákiai Asszonyok Lapja, a Prágai Magyar Hírlap mellékleteként, addig a másik kettő, a romániai Hölgyfutár és magyarországi Magyar Lányok, önálló lapként, heti és havi rendszerességgel kerültek kiadásra.

A nőkkel szemben támasztott elvárásokat, a foglalkozások terén betöltött szerepüket, erkölcsi nézeteiket, viselkedésüket szabályozó normákat, a nőolvasóknak szánt lapok jelenítették és jelenítik meg a legsokrétübben (Kádár 2002, 78). Mindazok a szerepkörök, amelyeket a kor a nökkel szemben elvár - jó anya, háziasszony, csinos nő - mind megfigyelhetőek a lapok hasábjain. Ezek együttesen fejezik ki az egyes kiadványok vélekedését a világról, és benne a nö által betöltött szerepekröl.

Nagyjából a 19. század végére, a 20. század elejére, mikor a Budapesten kiadott Magyar Lányok első számai megjelentek, tehető az egyre szélesedő magyar középosztálybeli női olvasóközönség fokozott térnyerése, és ezzel együtt a kifejezetten nőknek szánt sajtótermékek jelentőségének megnövekedése (Kérchy 2015, 82). A Magyar Lányok hetilap első száma 1894-ben jelent meg, és kisebb kihagyásokkal egészen 1944-ig jelennek meg példányai (Balog 2017, 60). Hiánypótlónak nevezhető, mivel a célközönségét kifejezetten a fiatal, serdülő, házasság 
előtt álló hölgyek alkotják. Az újság célja az általános müveltség kiszélesítése és a szórakoztatás mellett az, hogy praktikus, a mindennapi élethez elengedhetetlen tanácsokat kínáljon az olvasói számára, akár a pályaválasztás terén, akár a jövendőbeli családi praktikák tekintetében (Balog 2017, 60). Leegyszerüsítve, az életre való felkészítést tüzte ki céljául, amelyet olvasmányos formában tálalt. Többek között a házasodás elött álló hölgyeket látta el illemtanácsokkal, háztartással és szívügyekkel kapcsolatos tanácsokkal. A folyóirat elsősorban a konzervatív polgári közösség körében volt népszerü (Balog 2017, 60). A lap örökös szerkesztője Tutsek Anna volt, aki nemcsak mint szerkesztő müködött közre a lap megszületése után, hanem olykor a főoldalon szereplő felhívásokat és iránymutató cikkeket is közölt a lapban. A lap iránya nagyban függött az ő személyétöl és világnézetétől. Több cikkében hangsúlyozza, hogy a lap olvasóközönségéből egy erős, összetartó közösséget akar teremteni, akik ugyanazokat az értékeket követik. ${ }^{1}$ A szerkesztönő a kiadványaiban fontosnak tartja éreztetni ezt az ízlésformáló, identitásalakitó törekvést, amely a hüséges leányolvasókból igaz magyar háziasszonyt, honleányt kívánt nevelni a „Kinder, Küche, Kirche” konzervatív ideológiájának szentháromsága jegyében (Kérchy 2015, 83). A Magyar Lányok egy olyan folyóirat, amely bár a fiataloknak szól elsősorban, mégis felnőtt nőket érintő témákat taglal.

A másik vizsgált lap a kolozsvári kiadású Hölgyfutár, amely 1934 és 1938 között jelent meg Kolozsváron. Az alapító Szász Endréné Szappanyos Gabriella volt (Balogh 1991). Megjelenésének négy éve alatt a szerkesztője Szappanyos Gabriella volt mindvégig. Az ő tevékenysége is tovább terjed a lap szerkesztésénél, ugyanis olvashatunk tőle számos interjút és elbeszélést. A periodika a romániai magyar nőket célozza meg és a középosztályt érdeklő kérdésekkel foglalkozik. A működésének négy éve alatt, 1934 és 1938 között, a romániai magyar irodalom szinte minden rangos képviselöjét megszólította a hasábjain, és a modern román és egyetemes magyar irodalomból is igyekezett izelítőt adni (Balogh 1991).

A harmadik sajtótermék, amelyböl a tanulmány merít, az Asszonyok Lapja címet viseli. Ez a melléklet a Prágai Magyar Hírlapban jelent meg Prágában, 1934. január 6. és 1938. szeptember 8. között. A Prágai Magyar Hírlap a két háború közti csehszlovákiai magyar sajtóorgánumok közül a legszínvonalasabbak közé sorolható. 1922 júliusától 1938. november 5-éig jelent meg napilapként. Kétségkívül ez volt az egyik legolvasottabb lap a csehszlovákiai magyarság körében. Kiadói a kisebbségi magyarság ellenzéki politikai vezetői voltak. A lapot gyakran cenzúrázták, sőt volt olyan időszak is, 1933-ban és 1934-ben, amikor három-három hónapra betiltották (Balassa 2014, 21). A Prágai Magyar Hírlapra jellemző volt mindvégig, hogy támadta a cseh kormánypolitikát. Jellemzője, hogy gazdag volt az irodalmi és kulturális melléklete, ahová a magyarországi írói elit is szívesen küldött írásokat. Munkatársai voltak: Neubauer Pál, Darvas János, Győry Dezső és Szvatkó Pál. Legnevesebb főszerkesztője Dzurányi László volt 1925-től (Kenyeres Ágnes 1967-1994). Az Asszonyok Lapja melléklet jellemzője, hogy leginkább a szórakoztatást tűzte ki céljául. Sokat foglalkozik a divattal, szépirodalmi írásokat közöl, valamint házi praktikákat, recepteket is olvashatunk benne. 1938 szeptemberében

1 Tutsek Anna: Magyar Lányok tábori közleményei. Magyar Lányok, 1934. február 11. XL. évfolyam, 20. szám, 312. 
valószínűleg a politikai helyzet fokozatos feszültté válása miatt az Asszonyok Lapja melléklet abbamarad. A lap cikkeinek nagy részét ilyenkor már a bécsi döntés előzményének tekinthető politikai események teszik ki. ${ }^{2}$ Ez a három lap egyazon időben jelent meg, egyazon nemzetiség számára, három különböző országban.

Szerkezetüket tekintve az erdélyi magyarság körében megjelenő Hölgyfutár és a magyarországi Magyar Lányok nagyon hasonló lapok.

A Hölgyfutár, mivel havonta került kiadásra, ezért a terjedelme ehhez mérten hosszabb. a három közül a legterjedelmesebb. Ennél rövidebb a magyarországi Magyar Lányok, amelyet húszoldalas hetilapként adtak ki. A Prágai Magyar Hírlapban megjelenő Asszonyok Lapja a három lap közül a legrövidebb, mivel mindössze egy politikai napilap melléklete. Az 1934-es években még két-, olykor háromoldalnyi cikket foglalt magába, majd az évek elörehaladtával a nőknek szánt rovatok száma folyamatosan csökkent. Az 1938-as évre a melléklet féloldalnyi terjedelmúvé rövidült a vasárnapi kiadványban.

Mindhárom lapot jellemzi a vissza-visszatérő témák alkalmazása. Ha ezeket a visszatérő tendenciákat csoportosítani szeretnénk, akkor érdemes nyolc kategóriára osztani a cikkeket. Ez a nyolc kategória az alábbi:

- szépirodalmi cikkek

- nevelő célzatú cikkek

- szépséggel kapcsolatos cikkek

- hírek és ismeretterjesztő rovatok

- munkával és oktatással foglalkozó cikkek

- háztartással kapcsolatos cikkek

- szerkesztői üzenetek

- szórakozással kapcsolatos cikkek

Az újságok jellemzője, hogy nagyon hasonló rovatokat jelentetnek meg, azonban az nagyon is eltérö bennük, hogy mely rovatok milyen gyakorisággal és milyen mennyiségben vannak jelen a kiadványokban.

A Hölgyfutár 1934 és 1938 között kiadott példányaiban a fentebb felsorolt nyolc cikktípus közül mindet megtalálhatjuk. A lap mind a négy év alatt egy könnyen követhetö tendenciát folytatott, ami azt jelenti, hogy az egyes rovatok rendszerszerüen követik egymást. A Hölgyfutárban a szépirodalmi művek vannak túlsúlyban. Minden egyes számban vannak versek, elbeszélések, olykor regényrészletek, novellák. A szépirodalmi cikkeket gyakoriságuk arányában követik a hírek és ismeretterjesztő rovatok. A Hölgyfutárban szintén rendszeresen, de csak egyetlen rovat keretén belül találkozhatunk háztartással kapcsolatos cikkekkel és szerkesztői levelekkel. A legritkábban a hölgyek iskolázásáról olvashatunk ebben a lapban. Persze ez nem azt jelenti, hogy a nőről mint munkavállalóról nem esik szó szinte egyáltalán a lapokban, de ezzel a témakörrel inkább a neveléssel kapcsolatos cikkekben találkozhatunk. Ez abból következik, hogy ezek az írások nem magáról a munkáról szólnak, hanem tanácsokat adnak a nőknek, hogy hogyan viszonyuljanak az újonnan kialakult „kényszerhelyzethez”, amely a nőket kenyérkeresővé tette.

Az Asszonyok Lapjában szerkesztői leveleket nem olvashatunk, azonban annál

2 Sz. I: Megkezdödött a müncheni négyhatalmi konferencia. Prágai Magyar Hírlap, 1938. szeptember 30. XVII. évfolyam, 223. (4666) szám, 1. 
több a divatról és szépségápolásról szóló cikk (az összes rovat fele). A divatcikkek után jelentős számban vannak jelen még hírek és háztartási cikkek. Az Asszonyok Lapjában is találhatunk szépirodalmi alkotásokat, legtöbbször rövid történeteket és verseket.

A Magyar Lányokban szintén egy témakörröl nem esik szó, ez pedig a háztartási cikkek, tehát sem recepteket, sem otthonteremtö ötleteket nem közöl a lap. Az újság terjedelmének legnagyobb részét a szépirodalmi alkotások teszik ki. A szépirodalmon kívül számos hírt olvashatunk a lapban, valamint körülbelül ugyanolyan mennyiségben vannak a kiadványokban szórakozásra szánt keresztrejtvények és viccrovatok, valamint nevelési célzattal keletkezett cikkek. A legkevesebb cikk a szépséggel kapcsolatos.

Összességében megállapítható, hogy mindhárom lapnál ugyanazokkal a kérdéskörökkel foglalkoznak. Mindegyikben ugyanazok a témák jönnek elö, valahol terjedelmesebb formában, valahol csak emlités szintjén. Nagyon eltérő azonban a női szépséggel foglalkozó cikkek mennyisége és minősége. Az Asszonyok Lapjában fölöttébb nagy hangsúlyt fektetnek a női szépségre, hiszen minden számban van divatcikk és számos szépségápolási javaslat. Ezzel szemben a Hölgyfutárban csekély számú ilyen rovat van (a cikkek 7\%-a), a Magyar Lányokban pedig még ennél is kevesebb (a cikkek 1\%-a). Ami egyértelmüen közös mindhárom kiadványban, hogy a szépirodalmi cikkek közlésére egyaránt nagy figyelmet fordítanak, és az oktatással és a munkahelyekkel kevésbé foglalkoznak. Közös jellemzőjük még, hogy a nevelési célzatú cikkek hasonló arányban vannak jelen bennük, valamint, hogy a hírek és ismeretterjesztő rovatok a második legnagyobb terjedelmet teszik ki mindhárom újságnál.

\section{Az emancipáció megjelenése a sajtóban}

A továbbiakban azt vizsgálom meg, hogyan jelenik meg az elemzett három lapban a női emancipáció kérdése. A Hölgyfutár látásmódja már a lap legelső kiadásában megfogalmazódott, ugyanis rögtön az elején találunk egy tájékoztatót, amely tartalmazza, milyen irányt tűz ki maga elé a havilap. Így fogalmaznak: „Hát, ami ebből a folyóiratból kimarad, azt remélem senki sem fogja siratni. Deviza, valuta, gazdasági krízis, jobboldal, baloldal, hitlerizmus; mindezekről szó sem lesz ezeken a hasábokon. A közgazdaságot, politikát és más hasonlókat száműzzük innen. Mindezt rábízzuk a napilapokra. A Hölgyfutár foglalkozni fog mindazzal, ami a nöket érdekli, ami a nöknek való. Azt akarjuk, hogy ha a Hölgyfutárt kezébe veszi a gondterhes olvasó, felfrissüljön töle $s$ utána újult erővel mehessen vissza a nagy csatába, a napi gondok közé."3 Egyértelműen kivehető a szövegből, hogy a célközönsége a nök, és az is kiderül, hogy milyennek látja a lap az olvasóit. Kihangsúlyozza ugyanis, hogy minden „férfias” témát kerülni fognak, azon belül leginkább a politikát, valamint kiemeli, hogy a lap női olvasóinak való cikkeket és érdeklődésüknek megfelelő olvasmányokat fognak közölni. Az olvasók érdeklődési köréből a politikát és a gazdaságot automatikusan kizárja, vagyis egy nő szinte bizonyosan

3 Sz. I.: Ahogy megszülettünk. Hölgyfutár, 1934. április, I. évfolyam. 1. szám, 1. 
nem érdeklődik a politika iránt és ezért nem is érdemes ezzel untatni a lap olvasóközönségét. Beszoritják az olvasóikat abba a hagyományos nőképbe, amely szerint a nőket csak a pletyka és a szórakoztató cikkek tudják lekötni.

Az első számban felmerül többek között az erdélyi nők emancipációjának a kérdése is. A feminizmus és az erdélyi nők címü cikkben olvashatunk arról, hogy hogyan hatott az erdélyi nőkre a nyugatról érkező emancipáció. ${ }^{4}$ A cikk írója kifejti, hogy: „Erdélyben nyugatnak az egyenlő munkaidő es egyenlő bér megszerzése érdekében folytatott harcainak igen-igen halvány visszhangja van csak meg." $\mathrm{Az}$ erdélyi nőket a cikk elég maradi szemléletünek akarja láttatni. Az erdélyi nőkkel kapcsolatban a cikk írója kijelenti, hogy egyértelmüen nem feministák, és egyfajta követendő példaként állítja elénk őket, szembeállítva az amerikai hölgyekkel, akik életét túlzottan befolyásolták a modern változások. ${ }^{6} \mathrm{~A}$ cikk szerzője megállapítja, hogy az erdélyi nök körében nem igazán hatott az emancipáció, ugyanis ezek a hölgyek maradtak a konzervatív hagyományoknál. ${ }^{7}$

Van azonban elenyésző számú cikk, amely ezzel a konzervatív nőképpel éppen ellentétesen a modern nőt teszi pozitiv követendő példává. Így fogalmaznak: „... gondolkozás nélkül mindent átvenni előző generációktól csak azért, mert eleink is igy tettek, avagy mert mi is úgy nőttünk fel..." Ebből a mondatból már kitűnik, hogy a nőknek szabad és kell is igazodni a változó társadalmi normákhoz. „És nem szebb-e egy független, önálló, hasznos életet teremteni magának, mint a múlton sopánkodva másoknak terhére lenni?"9 A nőknek alkalmazkodni kell a társadalom változásaihoz, ami azt eredményezi, hogy önállóbbakká és függetlenebbekké válnak elödeikhez képest.

A Hölgyfutár néhány cikke bizonyos tekintetben támogatja az emancipációs törekvéseket, elsősorban a munkavállalás terén, de egyértelmüen elutasítja a hölgyek viselkedésében történő változásokat és nőiességük csökkenését a leghalványabb módon is. Például az egyik írásban olvashatunk tanácsokat arról, hogy hogyan is kell a nőnek viselkednie a munkahelyén, ha arra „kényszerül”, hogy férfiakkal dolgozzon együtt: „Ha kenyérkereső pályán vagyunk és férfiakkal együtt dolgozunk, bármennyire is sugároznunk kell magunkból az otthoniasság, a nőiesség, az anyaiság melegét és jóságát, azt mindenkor női méltóságunk megóvásával és a szükséges távolságok megtartásával kell tennünk. Akkor is, ha függetlenek vagyunk, de százszor inkább, ha házasságban élünk, vagy jegyben járunk. A túlságos enyelgés és pajzánkodás könnyen hamis vágányra tereli a kartársi viszonyt..."10 Ebböl a cikkrészletből a lapnak az a véleménye olvasható ki, hogy a nő a munkahelyén is maradjon ízig-vérig nő, védje erkölcseit, a méltóságát és tartson távolságot a kollégáitól, de azért sugározza az otthonias jóságot. A lap te-

4 Kovács Dezsőné: A feminizmus és az erdélyi nők. Hölgyfutár, 1934. április, I. évfolyam, 1. szám, 2. 5 Uo., 2.

6 Uo., 2.

7 Uo., 2.

8 F. Vadnai Hermin: Az édes mostoha. Hölgyfutár, 1934. április, I. évfolyam, 1. szám, 4.

9 Gróf Bethlen Györgyné: Ma-tehetség a nemeslevél. Hölgyfutár, 1934. június 15. I. évfolyam, 3. szám, 3.

10 Sz. I.: Féltékenység, Irigység - szeretet és tapintat a családi életben. Hölgyfutár, 1935. február 15. II. évfolyam, 1. szám,15. 
hát próbál egy olyan követendő nőideált kreálni, aki bár halad a korral, de megőrzi azokat az ősi értékeket, erkölcsiséget, amelyek eleink számára is sokat jelentettek.

Sok olyan cikk keletkezik, amelyben kritikusan állnak azokhoz a nőkhöz, akiknek az életében a kenyérkereset hangsúlyosabbá vált a háztartási teendőkkel szemben. Az egyik 1936-ban megjelent cikkben két fö csoportra osztja a szerző a nőket. ${ }^{11} \mathrm{Az}$ egyik nőtípusba sorolhatók azok, akik házon kívül dolgoznak, tehát kenyérkeresők. Az ő esetükben feltünni akarásnak nevezi a házon kivüli munkát, felrója nekik, hogy a házuk mérsékelten tiszta, a gyermekük pedig valószínüleg rendetlen. A háztartásban otthon tevékenykedőket viszont dicséri, hogy bár pénzt a munkájukért nem kapnak, de meglátni a családjukon a fegyelmezettséget. „Elvem: Igyekezzék a nő a százféle háztartási, gazdasági, kertészeti stb. munkákban érvényesülni, nem pedig az irodákban, gyárakban idő előtt felörlődni. Dolgozzanak a férfiak ezeken a helyeken erősebb szervezetükkel, és ha nem áll rendelkezésre a rengeteg női munkaerő, jobban megfizetik a férfimunkást..." ${ }^{12}$ Ebböl a kiemelt részletből is látható, hogy milyen szerepet szán a szerzője a nőknek és milyent a férfiaknak, valamint érdekes módon a nőket hibáztatja azért, hogy a férfiak fizetése nem elégséges egymagában a megélhetéshez. Azzal magyarázza ezt, hogy a nők elbitorolják elölük a munkahelyeket, ebböl kifolyólag ök kevesebb fizetést kapnak.

Vannak azonban ezzel ellentétes példák is, amelyek szerint a nőknek még több hivatásban ki kellene próbálniuk magukat. Az Egyenrangúan vagyunk-e ? $^{13}$ címü cikk 1935-böl arról szól, hogy a nők testi adottságaik révén sosem emelkedhetnek fel a férfiakhoz, de a nök könnyebb felfogásuk és alkalmazkodóképességük, valamint nagyobb akaraterejük és finomabb ösztönük révén semmivel sem kevesebbek a férfiaknál, tehát ugyanolyan értékű emberek, csak másban erősek. „El kell ismernünk, hogy évszázadokon keresztül, úgy társadalmilag, mint intelligencia dolgában a nőket a legalsóbb fokra kényszerítették. Ha megalkuvók lennénk, örömmel kellene regisztrálnunk az elért eredményeket."14 Kiemeli, hogy nem szabad megelégedni az eddig elért eredményekkel, hanem küzdeni kell, hiszen még csak félúton járnak a nők emancipációjában. ${ }^{15}$ Végül pedig arra a megállapításra jut, hogy a különbségek már az apró gyermekeknél elkezdődnek, hiszen az anyák máshogy szólnak egy kisfiúhoz, mint egy kislányhoz, és hogyha a nők egyenrangúságát el akarják érni, akkor a gyermekeket ehhez hozzá kell nevelni. ${ }^{16}$

A nők munkavállalását támogatja az Időszerü kérdések címü cikk is, amelynek az írónője vitára kel azzal a réteggel, akik a nők emancipációja ellen foglalnak állást. ${ }^{17}$ A cikkben megszólítja azt a maradi réteget, akik a negatívumot látják a dolgozó nőkben. A cikk elején kérdések formájában mutat rá a problémákra. „Mondja Uram, Ön előtt még mindig probléma a dolgozó nő? Ön a XX. század férfiúja még most is azt tartja, hogy vissza a nőknek a tüzhely mellé? Ön is azt tartja, hogy el-

11 Sz. I.: Újból a „dolgozó nőkröl”. Hölgyfutár, január 1. III. évfolyam, 1. szám, 3.

12 Uo., 3.

13 Sz. I.: Egyenrangúak vagyunk -e? Hölgyfutár, 1936. Ill évfolyam, 6. szám, 4.

14 Uo., 4.

15 Uo., 4

16 Uo., 4

17 Horváth Ella: Időszerủ kérdések. Hölgyfutár, 1935. júl.-aug. II. évfolyam, 6-7. szám, 3. 
veszik a kenyerét?" 18 A kérdésekre kivétel nélkül nemmel felel. Nemet mond arra, hogy a dolgozó nő probléma. Nemet mond arra, hogy a nők keresete nélkül meg lehetne élni, valamint egyenesen nevetségesnek tartja, hogy a férfiak elöl elveszik a női munkavállalók a kenyeret. Mellesleg a női munkavállalást leginkább kényszerhelyzetből kiinduló dolognak tartja. Így fogalmaz erről: „,Szívesen ülne minden dolgozó nő otthon és háztartana, de ez lehetetlen... stb."

A Magyar Lányokban, hasonlóan a Hölgyfutárhoz, az első szám beköszöntöjében kifejtik, hogy elsősorban milyen olvasóközönségnek szánják ezt a hetilapot. Ez a célközönség pedig a fiatal hölgyek. A cikkek tartalma alapján arra lehet következtetni, hogy leginkább a középiskola végéhez közeledő és a házasság elött álló hölgyeket szólítják meg, mivel számos olyan nevelő célzatú cikket jelentet meg, amelyekben ezeknek a hölgyeknek a viselkedésére akarnak hatni, ezzel kialakítva a tökéletes fiatal magyar nőideált. Egyértelműen meg akarja mondani a lap a hölgyeknek a helyes viselkedés szabályait, nem bízik abban, hogy a fiatal lányok önállóan, szabadon képesek eldönteni, hogy a viselkedésük helyes-e a kor számára. Ez pedig teljesen ellentétes az ekkoriban zajló emancipációs folyamatok hatásaival. A cikk írója ezt a nevelő szándékot nem is titkolja: „A komoly, nevelő irány mellett a Magyar Lányok szereti a vidámságot és derüt, a fiatalos, egészséges kacagást."19 A hölgyeket nagyon szigorú elvek szerint próbálja nevelni a lap.

A fiatal hölgyek számára az anyaságot tartja a legnemesebb foglalkozásnak: Mindannyiótoknak lesz majd az életben közötök a gyermekhez, akár, ha férjhez mentek, mint anyáknak, akár mint tanárnőknek, nevelőnőknek vagy ápolónőknek, mikor őrködnötök kell majd a reátok bizott gyermekek felett." A szakmák közül is azt tartja nőkhöz illönek, amelyekben gyermekekkel foglalkoznak.

Míg a nők belső értékeivel elég hangsúlyosan foglalkozik a lap, addig a külső megjelenésükkel szinte egyáltalán nem. A lelki műveltségben látja inkább a nőiességet, szemben a testi külsőségekkel. Az emancipáció témakörét inkább kerülni próbálják és helyette a régi értékeket hangsúlyozzák túl. A négy év alatt megjelent cikkekből az olvasható ki, hogy teljes mértékben a régi, hagyományos nőideál emelik piedesztálra és a modern, emancipált nőket megvetik. Azt tartják példaképnek, aki kedves, segitőkész, vallásos és a kikezdhetetlen az erkölcsi tisztasága.

Az Asszonyok Lapjában már egyfajta hangsúlyeltolódás következett be a modern nőkép irányába. $A$ nő önállósága című cikk szerzője például kifejti, hogy a mindennapi kenyérkereset már egyértelműen a férfi és a nő dolga egyaránt, azonban fontosnak tartja, hogy a nők tisztában legyenek a háztartási teendők elvégzésének mibenlétével. „Az elörelátó szülönek, vagy nevelönek gondolni kell arra is, hogy a leánygyermekböl mégis csak a maga asszonya lesz egyszer, a maga háztartásával kell foglalkoznia, úgy, hogy nem szabad egyoldalúan nevelni őket, mert ha férjet kap, az megkívánja, hogy a modern technika minden vívmánya mellett, háziasszony is legyen az otthonában." ${ }^{20}$ Ebből a cikkböl egyértelműen az rajzolódik ki, hogy a nőnek a házimunka elvégzése már nem a kizárólagos feladata, hanem sokkal összetettebb tevékenységre hivatott.

18 Uo., 3.

19 Sz. I.: Előfizetési felhívás. Magyar Lányok, 1933. október 1. XL. Évfolyam, 1. szám, 14.

20 Klári: A nő önállósága. Asszonyok Lapja, 1934. január 21., 17. 
Az Asszonyok Lapjában a nők mindennapi viselkedését nem akarják oly mértékben befolyásolni. Nem tüzik ki a nők elé az erkölcsösség zászlaját, hogy aztán az mögé felvonulva egy régimódi nőideált támogassanak. A nőket már sokkal egyenrangúbbaknak tekintik, amit a következő részletből is kiolvashatunk: „... azzal a maradi életszemlélettel szemben, amely még manapság is oda tapsolná ôt az anyja szoknyájához, a himzőráma, a konyha és a zsalugáteres ablakok mögé, úgy, ahogy azt régi, érzelgős poéták emlékkönyvekbe irt verseiben olvashatjuk..."21 Surányi Miklós írásában a nőket teljesen egyenlőnek tekinti a férfiakkal, bár fenntartja azt, hogy a véleményével sokan nem értenek egyet, és inkább látnák a hölgyeket a régi, megszokott szerepköreikben. Ő azonban ezt elvetve támogatja a nők megjelenését sokkal több színtéren. A cikk folytatásában erröl így ír: „,...szellemi képességek dolgában egy lépéssel sem áll mögötte a férfiaknak. Ma a nő egyszerre vetélytársa lett a férfinek tudományban, művészetben, mesterségben, munkában, vagyonszerzésben, sportban, nyaktörő vállalkozásokban, sőt még a leginkább nyaktörő sportban - a politikában is..."22 Ebben a lapban már az okos asszony ugyanannyira - ha nem jobban - megbecsült személy, mint a házias feleség. A másik két újsággal ellentétben, ahol a lányokat a tartózkodó, erkölcsös magatartásra nevelik, az Asszonyok Lapjában a nők kendőzetlenebb módon mernek bizonyos témákról beszélni. Míg a másik kettőben kevésbé lehet elképzelni azt, hogy a szerzők olyan cikkeket írjanak, hogy a nők hogyan hódítsák meg a kiszemelt férfit, addig az Asszonyok Lapjában több ilyen írást és az ezekre irt válaszleveleket is olvashatunk. Például a Ne fuss a férfi után címü cikkben így írnak: „...bármennyire is modernizálódik minden körülöttünk, vannak természetadta dolgok, amelyek örökéletüek maradnak, így a férfi természete is örök. A férfi nem akar meghódittatni..."23

A lapban fel mernek tenni olyan komoly kérdést is, hogy hátrány-e nőnek születni és meg is válaszolják ezt. Ez a cikk nagyon keserü képet fest a női emancipációról. Olyan alapvető mindennapi mozzanatokig vezeti vissza a témát, amely valóban minden nőt érint. Például felveti azt, hogy már a születéstől fogva a lányok hátrányból indulnak. Így fogalmaz: „A nő már születésekor hátránnyal indul a férfiakkal szemben. Ha fiúgyermek születik, ezt diadalmasan jelentik be az ismerösöknek, ha pedig leányzó az újszülött, akkor sajnálkozással, sokszor bosszúsággal fogadják érkezését. "Csak leány« - mondja gyakran az apa savanykásan." ${ }^{24}$ Már ebből a mondatból ki tudjuk következtetni, hogy a címben feltett kérdésre végül az írónő válasza az lesz, hogy igenis hátrány ebben a korban nőnek születni. Szerinte a nők mindig mellözve voltak, még akkor is, ha valamiben lehetöségük lett volna kitörni: „... a mellőzés végig kíséri a nőt egész életén. Vagy nem engedik megfelelően érvényesülni, vagy ha a férfiak által elébe rakott akadályok dacára is eredményeket ér el, akkor azt lekicsinylik, nem méltányolják eléggé. Viszont, ha a férfiak érnek el sikert valami tipikusan női foglalkozási ágban (mint például főzés, ruhaszabás), akkor ezt dicséröleg kürtölik világgá." 25

21 Surányi Miklós: A ma asszonya. Asszonyok Lapja, 1934. márc 11., 17. 22 Uo., 17.

23 Sz. I.: Ne fuss a férfi után! Asszonyok Lapja, 1934. február 11., 17.

24 Sz. I.: Hátrány-e nőnek születni? Asszonyok Lapja, 1935. január, 17.

25 Uo., 17. 
A felsoroltak ellenére nem jelenthetjük ki minden kétséget kizáróan, hogy az Asszonyok Lapja az emancipációt mindig minden hozadékával együtt támogatja. Ami viszont kijelenthető, hogy a másik két laphoz viszonyítva sokkal több pozitívumot lát a nők emancipációjában.

Mindhárom lapban, bár nem nagy terjedelemben, de jelen vannak olyan cikkek, amelyek különböző pályákat mutatnak be. Ezekböl a pályabemutatókból is könynyen lehet következtetni a lap hozzáállására a női egyenjogúság kérdéséhez.

A népszerüsített pályáknak az a közös jellemzője, hogy kifejezetten a nöknek szánják öket. Ezek az írások legtöbbször a foglalkozás elsajátításának mikéntjét mutatják be, népszerüsítenek különböző intézményeket és olykor az elhelyezkedési lehetőségekröl is beszámolnak.

A Magyar Lányok viszonylag hangsúlyosan foglalkozik a különbözö, nőknek való szakmák népszerüsitésével, ami abból is adódhat, hogy a lap célközönsége a 16 és 20 év közötti nők. A Magyar Lányokban népszerüsített szakmáknak a közös jellemzője, hogy többnyire az oktatáshoz és a betegápoláshoz kötődnek. A propagált szakmákat három nagy kategóriába sorolhatjuk. Az első a gyermekneveléssel, a második a betegellátással, a harmadik pedig a háztartással kapcsolatos foglalkozások.

Nagyon megbecsült hivatásként tekintettek például a tanítói pályára. Úgy írnak róla, hogy ez egy olyan hivatás, amely folytatása az otthoni nevelésnek. ${ }^{26}$ Ezért is tekintik tipikusan női foglalkozásnak. Így írnak erről: „A kisgyermekek tanítása ösidőktől fogva női munka volt." 27 A tanítókra úgy tekintenek, mintha a tanítványaiknak félig-meddig a „,kismamájuk”28 lenne. Ebböl az derül ki, hogy a tanítói szakma azért is elfogadható és népszerű a nők körében, mert nagyon szorosan kötődik az otthoni anyai szerephez. Hasonlóan vélekednek az ápolónőkröl és a védőnőkröl, akiknek a munkaköre szintén köthetö az otthoni, tipikusan nök által végzett feladatokhoz. A harmadik terület, amelyen belül a lap foglalkozási lehetöségeket ajánl, az otthoni háztartási teendökhöz hasonlatos munkakörökre hasonlít leginkább.

A Hölgyfutárban nagyon hasonló konzervativ véleményeket fedezhetünk fel, mint amelyek jelen vannak a Magyar Lányokban. A munkavállalás terén még inkább a konzervativ értékek mellett állnak ki. Bár tisztában vannak a változó világ tendenciáival, mégis arra törekednek a cikkekben, hogy az ősök hagyományait a fiatal generációk megőrizzék. Erre erősítenek rá egy cikkben, amelyben arról írnak, hogy a mai fiatal hölgyeket a kenyérkereső anyáknak nincs idejük megtanítani a háztartási teendők megfelelő elvégzésére. A cikk írója megjegyzi, hogy az iskolai keretek közt mennyire fontos a háztartási oktatás, mivel attól, hogy a hölgyek kenyérkeresővé váltak, a háztartási teendőik sem szorultak hátrébb a ranglistán, ugyanis a nő feladata és kötelessége maradt továbbra is a munka beosztása, ellenörzése, a pénz elosztása, felhasználása. ${ }^{29} \mathrm{~A}$ cikk elutasítja, hogy a nök azért vállaljanak hivatást, mert kedvük van valamihez és hasznos részei akarnak lenni a társadalomnak, nemcsak mint szülő nők, hanem mint komoly, megbízható, kar-

\footnotetext{
26 Sz. I.: Milyen pályára menjek? Tanítónéni. Magyar Lányok, 1935. február 24. XLIl. évfolyam, 22. szám, 270.

27 Uo., 270.

28 Uo., 270.

29 Dr. Döriné Kováts Jolán: Leányaink háztartási nevelése. Hölgyfutár, IV. évfolyam, 4. szám, 4.
} 
rierrel rendelkező hölgyek: „,...a házi munka, már természetétől fogva a nő igazi hivatása. - Miután nagyon sokan nem szoktatják a leányokat a háztartásban való segitésre, a gyermeknek legtöbbször veleszületett készsége elvész." ${ }^{30}$ Ez a részlet bár közvetett módon, de elutasítja azt, hogy a férfi is segítségére lehet a nőnek a háztartási teendők elvégzésében, hiszen miért is lenne, ha a nö úgy születik, hogy ez a kijelölt feladata. A női nem képviselöit konkrétan a házi munkára teremtették, ezt mondja ki. A cikk beszoritja a nőket az addigi hagyományos szerepkörökbe.

Az Asszonyok Lapjában található állásehetőségek és a tanfolyamokról szóló tájékoztatók sokkal tárgyilagosabbak a másik két laphoz viszonyítva. A cikkben a szakmák mellett nem foglalnak állást, nem értékelik, hogy az egyes tanfolyamok nőnek vagy nem nőnek valóak. Persze a cikkből kiderült, hogy kifejezetten nők számára indul a tanfolyam, azt nem lehet elvitatni, de mégsem sulykolja bele az olvasóba, hogy mennyire nőies is egy bizonyos hivatásban való helytállás és egy konkrét szakma elsajátítása. Így fogalmaznak a háztartási alkalmazotti képzésről: „A felvételnél igazolni kell a csehszlovák állampolgárságot, a szegénységet és az eddigi kifogástalan erkölcsi magaviseletet. A cél az, hogy a háztartás minden ágában jártas és megbízható háztartási alkalmazottak képeztessenek ki, kik a háziasszonyoknak nemcsak támaszai, hanem a háztartást önállóan és takarékosan is vezetni képesek legyenek. El kell sajátítaniok a takarítást, a bútorok tisztántartását és kezelését az egyszerü és díszes asztalterítést valamint az asztalnál való felszolgálást egyszerü és ünnepi alkalmakra való főzést, a fehérnemű gazdaságos és kíméletes mosását. A gyermekgondozást és egyszerü női ruha, valamint fehérnemü varrását. A tanfolyam elvégzéséről az illetők bizonylatot kapnak." ${ }^{11}$ Mint itt is olvasható, a cikk írója felsorolja, hogy ebben a munkakörben, ha elhelyezkednek, a nöknek mire is kell majd számítaniuk, valamint, hogy mik a feltételei annak, hogy a képzésre felvételt nyerjenek. Nem fejti ki, hogy ez a szakma mennyire nőies és mennyire hölgyhöz méltó. Nem próbálja befolyásolni az olvasót, viszonylag tárgyilagos a megfogalmazása.

Egy másik cikkben, ahol egy szakmát mutatnak be, amelynek a neve próbakisasszony, amely talán a mai modellnek felelhet meg, sokkal tárgyilagosabban teszik ezt, mint bármely más szakmát bemutató cikk a Magyar Lányok vagy a Hölgyfutár hasábjain. Olvashatunk ebben a cikkben arról is, hogy ez milyen jó lehetőség ez a munka a szegényebb sorsú hölgyek számára. „Ebben a foglalkozásban jóformán nem ismernek korhatárt. A kereskedelmi iskolát most elvégzett 17 éves lányok, akik mint gépírónők vagy levelezőnők nem tudtak elhelyezkedni, épp úgy megtalálhatók itt, mint azok a negyvenéves asszonyok, akik jó alakjukat megtartották és akik különösen az idősebb hölgyek számára készült ruhák bemutatásában jeleskednek. Van olyan mannequin is, aki már tizenöt éve teljesít szolgálatot az egyik nagy bécsi divatáruháziban..."32 Egy újabb nagyobb különbség a másik két laphoz képest a népszerüsített szakma típusa, ugyanis ez a próbakisasszonyi állás semmilyen módon nem passzol bele a Magyar Lányok és a Hölgyfutár szemléletébe, amely szerint a külsőségek nem fontosak. A három nagy kategória közül, amely köré a nőknek való állásokat szövik, vagyis az ápolói, nevelö, háztartási munkák, ez seho30 Uo., 5.

31 Sz. I.: Háztartási alkalmazottakat képző ingyenes tanfolyam. Asszonyok Lapja, 1938. augusztus 21., 18.

32 Sz. I.: A próbakisasszonyok élete. Asszonyok Lapja, 1937. február 28., 18. 
vá sem illeszthető be. Az Asszonyok Lapja tehát valamelyest ebben is eltér a többi laptól, hiszen nem tartja megbotránkoztatónak a női szépséggel való pénzkeresést.

Megállapítható tehát, hogy a Magyar Lányokban és a Hölgyfutárban a népszerüsített szakmák a konzervatív hivatások közé tartoznak. Ez azt jeleni, hogy a hölgyolvasóik számára olyan szakmákat népszerüsítenek, amelyek valamilyen módon kapcsolódnak azokhoz a munkakörökhöz, amelyek a múltban úgymond a nök feladatai közé tartoztak. Az ilyen témájú cikkek sajátossága továbbá, hogy a nőket megpróbálják befolyásolni oly módon, hogy ezeknek az álláslehetőségeknek kiemelik a pozitívumait, továbbá azt, hogy ezek a szakmák mennyire nőknek valók, és még azt is hangoztatják, hogy a nők ezekre a munkákra születtek.

Ezzel szemben az Asszonyok Lapjában az ebben a témakörben megjelentetett cikkek sokkal tárgyilagosabban mutatják be a képzéseket és az állásokat. A befolyásoló szándék is sokkal kevésbé észlelhetö, valamint az itt bemutatott szakmák már nem teljesen ragaszkodnak a korábbi női szerepkörökhöz, el mernek rugaszkodni azoktól, és a nőiességet is merik népszerüsíteni.

\section{Összegzés}

A nők társadalmi szerepe a két világháború közötti időszakban drasztikus változásokon esett át mind a politika, mind a munkavállalás és az oktatás terén. A nők egyre több szerepben jelentek meg és egyre nagyobb megbecsülést vívtak ki maguknak. Azonban a nők megszokott szerepeikből való kilépését nem mindenki fogadta kitörő örömmel. Az addig nagy részben férfiak által irányított világ nehezen fogadta el ezeket a változásokat.

Az általam vizsgált lapok nagyon jól bemutatják a nőket ekkoriban érintő mindennapi problémákat, kérdéseket. Foglalkoznak az életüket befolyásoló dilemmákkal és társadalmi jelenségekkel. A szórakoztatás mellett komoly kérdésekkel is foglalkoznak, mint például valóban hátrány-e nőnek születni, vagy hogy a nyugaton erőteljesen zajló emancipáció hatásai miként jelennek meg a kelet-európai országokban és hogyan befolyásoljak az itt élő nők életét. A vizsgált lapok oldalain gyakran olvashatunk olyan véleményeket, amelyek szerint a nőknek továbbra is a háztartási teendőkkel és a gyermekneveléssel kellene kizárólag foglalkozniuk.

Ha sorrendbe tennénk a lapokat a legkonzervatívabb felöl haladva a legliberálisabb felé, akkor a legkonzervatívabb szemléletünek a magyarországi megjelenésü Magyar Lányokat tekinthetjük, amely egy maradi nőideált vetít az olvasók elé és azt tartja követendő példának. Ennél liberálisabb a Hölgyfutár, a három közül a legliberálisabbnak pedig az Asszonyok Lapja nevezhetö.

A Magyar Lányok cikkei szerint a fiatal hölgyek csakis jó tulajdonságokkal bírhatnak: előzékenyek, visszahúzódóak, viselkedésük minden helyzetben kifogástalan, valamint fontos náluk a vallás és az, hogy a házasságukig őrizzék a szüzességüket. Az ideális hölgyek bár képzettek, de szakmájuk nem terjed tovább az olyan foglalkozásoknál, mint például az óvónői, tanári, védőnői szakma, amely szakmák maximálisan megfelelnek a nők addigi háztartásban és gyermekneveléssel kapcsolatban végzett tevékenységüknek. A Magyar Lányok cikkei szerint nem kell foglalkozni a 
női emancipációval, és meg kell elégedni az e téren eddig elért eredményekkel. A magyarországi nőkkel kapcsolatban arra a megállapításra juthatunk, hogy számukra a nöi emancipáció csak minimális mértékben fontos, és a harmincas években még közel sem tekintettek rájuk a férfiakkal egyenrangúként. A Magyar Lányokban nem foglalkoznak azzal, hogy olvasóikat buzdítsák a női egyenjogúság kivivására.

A haladóbb szellemü erdélyi Hölgyfutár bár valamelyest pozitívabbnak tartja a nők emancipációját, azonban maradi szemléletű cikkeket is olvashatunk benne, amelyek írói a hölgyeket leláncolnák az otthoni tűzhely mellé. A lap szerkesztősége a nők munkavállalását kényszerhelyzetnek állítja be, ami egyértelműen azért szükséges, mert a férfiak keresete már nem elegendő a család számára, így a nők is kénytelenek kivenni a részüket a pénzkeresetből. Számos cikkben az emancipációt hangoztatják, de a nők teljes egyenlőségét nem tartják magától értetődő dolognak. Elfogadják másodrendüségüket a férfiakkal szemben bizonyos helyzetekben, de látják a következő generációk feljebb jutásának esélyeit. Számtalan ellentmondásos nézettel találkozhatunk a lapban.

A Hölgyfutár nőideálja már próbálkozik az arany középút megtalálásával, de mégis inkább a konzenatívabb oldalhoz áll közelebb. Az erdélyi lap szerint az ideális nő olyan, aki már helytáll az újabb társadalmi változásokkal tarkított világban, de a tradíciókról sem feledkezik meg. Fenntartja az olyan kettőség lehetőségét is, amely szerint a nőknek a teljes emancipációra kell törekednie, de azt is, hogy mindeközben maradjanak meg az eddig megszokott szerepkörökben. A romániai társadalom számára, a cikkekből következtetve, a konzervatív értékek a legfontosabbak, de mégis lényegi különbség a magyarországival szemben, hogy már sokkal nyitottabbak a változásokra. Abban is haladóbb szelleműek, hogy bizonyos mértékben pozitivabbnak tartják a nők emancipációját. Mindeközben nem kedvelik az olyan nőket, akik karrierépítésre adják a fejüket, ahelyett, hogy a háztartásba és a gyermeknevelésbe fektetnék az idejüket. A lap által bemutatott társadalom a harmincas években is úgy gondol még a nöi munkavállalásra, mintha az csakis kényszerből történne és nem a nők szabad elhatározásából. A lap eldöntetlennek láttatja azt a kérdést, hogy vajon a nőknek a teljes emancipációra kell törekedniük vagy meg kellene maradniuk az eddig megszokott szerepekben.

Az Asszonyok Lapjában megjelenö írások döntő többsége támogatja az emancipációt. Ebben a lapban már fel sem merül az a gondolat, hogy a nők ne lennének egyenlőek a férfiakkal, legalábbis a szellemi képességek terén, de azért több esetben a hátrányuk egyértelmüen érződik. Ezt a hátrányt azonban le lehet és le is kell győzni. Ki kell harcolni az azonos bánásmódot minden térén, hogy a nők bármilyen hobbit üzhessenek és bármilyen foglalkozást, amire kompetenciájuk van, elvégezhessenek. A Hölgyfutárhoz hasonlóan itt is találunk egymásnak ellentmondó cikkeket. Sok nő például véleményét kifejtve harcol azért, hogy egyenrangúként tekintsenek rá, míg más nők ezt nem tartják fontosnak. Az ideális nővel kapcsolatban is több elképzelés merül fel, azonban mindegyik típus jellemzője, hogy a másik két laphoz képest közelebb áll a nyugati mintákhoz. Az Asszonyok Lapjában egy modern, divatot követő, a háztartásban helytálló, de a tevékenységét koránt sem erre korlátozó nő tárul elénk, aki, ha akar valamit, azt eléri. Ez a hölgy a férfiak véleményének olykor akár ellentmondani is képes, mondhatni „,vagány” nő, aki bár az 
akkori nőkhöz képest valóban modernebb, a maihoz viszonyítva még közel sincs az emancipáció csúcsán.

Az Asszonyok Lapjában a csehszlovák társadalom a másik kettőhöz viszonyitva jóval modernebbnek rajzolódik ki. Itt már fel sem merül az a gondolat, hogy a nők ne lennének egyenlőek a férfiakkal a szellemi képességeikben. Az is utal a csehszlovákiai nők modernebb életvitelére, hogy a divattal sokkal többet foglalkoznak, valamint nem akarják őket a lapokban megnevelni. Tanácsokat persze adnak számukra, de mégsem vetik a szemükre, ha viselkedésükben nem a leghagyománytisztelöbbek. A divatcikkek a párizsi divatot követik és számos nyugati szemléletet népszerüsítenek. A cikkek olyan hölgyeknek és hölgyekröl szólnak, akiknek van szabad akaratuk és saját véleményük, amelyeket akár közölhetnek is a lap hasábjain. Ezek akár abból is következhetnek, hogy az újonnan alakult Csehszlovák állam demokratikus keretek között jött létre és a nök is hamar szavazati joghoz jutottak, miközben példának okáért Magyarországon csak bizonyos kitételekkel valósult ez meg, Romániában pedig csak 1948-ban kaptak a nők szavazati jogot. A nők szavazati jogának megadása is azt erősíti meg mind a nők, mind a férfiak részéről, hogy a hölgyek semmiben sem alacsonyabb rendűek, és képesek akár az ország vezetésével kapcsolatos komoly kérdésekben is döntést hozni.

Bár egy-egy lap elemzése során nem lehet átfogóan megítélni az országok társadalmának viszonyulását a női emancipáció kérdéséhez, mégis számos dolgot meg tudunk róluk állapítani. Ízelítőt kaphatunk arról, hogy a kor társadalma hogyan viszonyult a női olvasókhoz, milyennek látta a helyzetüket a világban és az adott országban. Betekintést nyújtanak még abba is, hogy a harmincas években hogyan vélekedtek a női munkavállalásáról, a női egyenlőségről és a női szerepkörök megváltozásáról.

\section{Irodalom}

Bajcsi lldikó (2014): Női szerepek kisebbségi helyzetben, Magyar női sorsok a kétvilágháború közötti Csehszlovákiában. Fórum Társadalomtudományi Szemle, 16. évfolyam, 1. szám, 131-156.

Balassa Zoltán (2014): A cenzúra története Csehszlovákiában 1918-1992: A magyar sajtószabadság lehetöségei. In: Apró István - Paál Vince (szerk.): A határon túli magyar sajtó Trianontól a XX. század végéig: Fejezetek a magyar sajtószabadság történetéből. Médiatudományi Intézet, 11-52.

Balog Beáta (2017): Életreformelemek megjelenése az 1920-1930-as években a Magyar Lányok címü folyóiratban. In: Németh András - Vincze Beatrix (szerk.): Neveléstudománytörténeti tanulmányok: Továbbélő utópiák - magyar életreform-törekvések és nemzetközi recepciós hatások. Budapest: Gondolat Kiadó, 58-81.

Balogh Edgár (1991): Romániai magyar irodalmi lexikon: Szépirodalom, közírás, tudományos irodalom, müvelödés II. (G-Ke). Bukarest: Kriterion.

Dudeková, Gabriela (2015): Család és túlélési stratégiák az I. világháborúban: Hosszú távú változások a szlovák társadalomban. Világtörténet, 37. évfolyam, 2. szám, 311-333. 
Fenyő István - Ugrin Aranka - Kosáry Domokos - T. Erdélyi llona (1985): A magyar sajtó története II/2. 1867-1892. Budapest: Akadémiai Kiadó.

Gyáni Gábor - Kövér György (2006): Magyarország társadalomtörténete a reformkortól a második világháborúig. Budapest: Osiris Kiadó.

Horváth Ágnes (2017): A nők választási aktivitása a két világháború között. In: Torgyik Judit (szerk.): Válogatott tanulmányok a társadalomtudományok köréből. Komárom: International Research Institute s.r.o., 272-280.

Kádár Judit (2002): „Otthonod az uradé”. Három 20. századi magyar képes hetilap nőképe. Médiakutató, 9. szám, 78-94.

Kenyeres Ágnes (1967-1994): Magyar életrajzi lexikon I-IV. Budapest: Akadémiai Kiadó.

Kérchy Anna (2015): Hebrencs kisleányból kötelességtudó honleány: Nőképváltozások a Magyar Lányok hetilap első világháború alatti lapszámaiban. Médiakutató, XVI. évfolyam, 2. szám, 81-95.

Mongu, Blanka (2007): Percepcia Ameriky v československej tlači a vplyv Američanky na obraz modernej ženy v Československu v rokoch 1918-1938. Slovenská literatúra, 54. évfolyam, 4. szám, 277-282.

Pukánszky Béla - Németh András (2013): A nőnevelés története. Budapest: Gondolat Kiadó.

Tomka Béla (2006): Bevezetés Európa újabbkori társadalom- és gazdaságtörténetébe. Szeged.

Vajda, Barnabas et al. (2016): Forms of Political and Media Propaganda in Central Europe, Czecho-Slovakia and Hungary. Komárom: Selye János Egyetem Tanárképző Kara.

\section{Források}

Asszonyok Lapja 1934-1938.

Hölgyfutár 1934-1938.

Magyar Lányok 1934-1938. 